\title{
Formal Analysis and Principal Architectural Character of Caunus Theater
}

\author{
Kaunos Tiyatrosu'nun Biçimsel Analizi ve Temel Mimari Karakteri
}

\author{
Yasemen SAY ÖZER, ${ }^{1}$ Nevzat Oğuz ÖZER²
}

\section{ABSTRACT}

The ancient city of Caunus lies on the southwest shore of Anatolia, across the island of Rhodes. In the present time, it is located within the borders Köyceğiz town and is on the western bank of the Dalyan River, which connects Lake Köyceğiz with Mediterranean Sea. A port in earlier times, the city now is at quite a distance from the seashore due to the formation of the Dalyan Delta. Its harbor's location was strategically important for ships sailing between Aegean Sea and the Eastern Mediterranean. The Caunus Theater, situated towards southwest and overlooks the city and sea, is one of the best preserved among the Anatolian theaters as well as other structures of Caunus. Owing to the topography of the site, while the seats situated on the east of the theatre are located on a reformed rock, the seats on the north and west are supported by analemma. Analemma along with some of the seats and the stage are currently in ruins. However, during the process initiated by the founding of an "archeological park" in the city together with its immediate surroundings, a detailed architectural documentation of the city buildings has been planned. This documentation aims not only to document the buildings in isolation but also to indicate the location of the buildings within the city and the relations between the buildings and the topography. Digital coordinate measuring equipment are used for measuring the land, and the fundamental geometry of the theater are recorded in detail. All structural elements are measured meticulously, and a detailed 3-dimensional picture of the theater is created, from which a restituition model is generated in digital format. We have attempted to identify the principal characteristics of the structure using simulations performed on the digital model.

Keywords: Antique theater; Caunus; Greek theatre; Vitruvius.

ÖZ

Türkiye'nin önemli ören yerlerinden biri olan Kaunos antik kenti, Güneybatı Anadolu'da, Akdeniz ile Ege Denizi'nin birbiriyle kesiştiği bir bölgede, Rodos Adası'nın karşısında, Köyceğiz Gölü'nü Akdeniz'e bağlayan Dalyan Çayı́nın batı kıyısındadır. Kaunos antik kenti, Akdeniz ve Ege Denizi arasındaki stratejik konumundan ötürü önemli bir liman kenti olarak kurulmuştur. Kentin limanı, zamanla Dalaman Çayı́nın yüksek dağlardan getirdiği alüvyonlarla yatağını doldurması ve daha sonra da yatağını değiştirmesi ile bataklık haline gelmiştir. Limana gemilerin giremeyerek ticaretin yok olması ve bataklıklardan kaynaklanan hastalıkların artması ile ölü bir kent haline gelmiştir. Güneybatıya yönlendirilmiş yerleşimiyle kente ve denize hakim konumdaki Tiyatro, sadece kentin ayakta kalmış diğer yapıları arasında değil, Anadolu Tiyatroları içinde de en iyi korunmuş olanlarından biridir. Topografyasından kaynaklı olarak, tiyatronun doğu bölümünde yer alan oturma basamakları, düzeltilmiş anakaya üzerine yerleştirilmişken, kuzey ve batı bölümünde bulunan oturma basamakları ise analemma ile desteklenmiştir. Günümüzde, analemma ve oturma basamaklarının bir bölümü ile sahne binası yıkık durumdadır. Kentin yakın çevresiyle birlikte bir "Arkeolojik Park" olarak değerlendirilmesiyle başlayan süreçte, kent yapıları için ayrıntılı mimari belgeleme yapılması hedeflenmiştir. Bu belgeleme, sadece yapıların tek başlarına ölçülmesini değil; aynı zamanda yapıların kent içindeki konumları, birbirleri ve topografya ile ilişkilerinin değerlendirilmesi amacını da taşımaktadır. Arazi ölçümleri, sayısal koordinat ölçme cihazı ile yapılmış ve tiyatronun temel geometrisi hakkında detaylı bir kayıt elde edilmiştir. Tiyatronun yapısal unsurları taş taş ölçülerek, tiyatronun ayrıntılı üç boyutlu bir resmi elde edilmiş ve bundan yararlanarak sayısal ortamda bir restitüsyon modeli üretilmiştir. Bu model sayesinde kullanımdan kaynaklanan çeşitli durumlar canlandırılmak sureti ile yapının temel karakteristikleri bulunmaya çalışılmıştır.

Anahtar sözcükler: Antik tiyatro; Kaunos; Yunan tiyatrosu; Vitruvius.

'Department of Architecture, Yıldız Technical University, İstanbul, Turkey ${ }^{2}$ Department of Architecture, Mimar Sinan Fine Arts University, İstanbul, Turkey

Article arrival date: Nisan 18, 2016 - Accepted for publication: Mart 21, 2017

Correspondence:Yasemen SAY ÖZER. e-mail: yasemen@yildiz.edu.tr 


\section{Introduction}

The ancient city of Caunus is situated right across the Dalyan neighbourhood, along the banks of the Dalyan River which connects the Köyceğiz Lake to the Mediterranean Sea. It is located within the boundaries of the Çandır neighbourhood of the Köyceğiz district in the Muğla province. The city is bordered by the Sivrihisar Hill and Balıklar Mountain on the North and the West which are the extensions of the Ölemez Mountain. The city oversees Likya on its East and South. On its southwest, Rhodes Island is $60 \mathrm{kms}$ away. The location of its harbour was strategically important for ships sailing between the Aegean Sea and the Eastern Mediterranean. Therefore, the great powers at different times in antiquity fought bitterly with each other to control this harbour city. The city now lies about $8 \mathrm{kms}$ away from the seashore due to the formation of the Dalyan Delta. This makes Caunus more important than its contemporary cities not only in historical or geopraphical aspects, but also in political and social life as well as in economical and cultural changes. ${ }^{1}$ The site of the ancient city was first discovered by Richard Hoskyn, ${ }^{2}$ and the archaelogical excavations in the area were initiated by Prof. Dr. Baki Öğün in 1966. ${ }^{3}$

Between the years 2013-2015, using a 3D measuring equipment, coordinates are calculated using 18,000 landmark points on the Caunus Theatre and with the data acquired, a 3D model of the Theater is formed. The aim of this study is not just to establish architectural documents about this impressive building, but also to find out important evidence about the formation and the topography of the city. Documenting the basic form of the structure and unearthing the architectural character of the theatre will present us with data that can be used in other studies in this field. On the other hand, another aim of the study is not to date the structure, but to give an objective view of the data required for dating. This article encompasses the analysis of the drawings created using the CAD software provide the capability to draw quite detailed $3 \mathrm{D}$ and $2 \mathrm{D}$ drawings of the monument.

\section{Architectural Description of the City}

It will be helpful to explain briefly the architecture of the city and the architectural attributes specific to itself before describing the theatre.

The most important attribute of the ancient city Caunus, which is a harbour settlement, is its topography. The main decisive factor in the formation of the city and the location and design of the structures has always been the topography and the terraces resulting from it. In this context, Caunus is a city of terraces. In the ancient cities, ter-

\footnotetext{
1 Öğün vd., 2001, 1. $\quad 3$ The current excavation works are being conducted

2 Hoskyn, 1842, 144. by a team led by Prof. Cengiz Işık since 2001.
}

races have been seen as the formal evidence of the will to live as a community. ${ }^{4}$ On the other hand, terraces point to rapidly growing and developing cities in the Hellenistic Age. ${ }^{5}$ The physical growth of the city has been achieved by creating plains out of slopes and building on these plains. As can still be seen, Caunus is a settlement where, beginning from the harbour, structures are built upon terraces. These terraces are on the slopes around the city and upon the hills (Fig. 1).

Almost all the public buildings, such as the Roman Bath, the church and the theater are built on man-made terraces. The Theater, which is at the western slope of the Acropole, is located at the easternmost plot of the pinnacle line between Sivrihisar Hill and the Grand Acropole. This pinnacle line has been shaped by terraces and important public buildings built upon them. In this big space, which is called Upper Terraces, starting from the West, following buildings exist: "Corinth Temple", which is built on a rock, "Bathhouse from the Roman Age", Palaestra Terrace upon which the "Domed Church" is built, which is one of the best preserved Early Period churches of Anatolia, Survey Platform in the south, and the Theater at the east end (Fig. 2). The east of the theater is on the slopes of the Grand Acropole, and the west side stands on a structure supported by cavea wall built on a terrace. The theater, with a supreme view of its surroundings, is one of the most impressive buildings in the city without a doubt.

\section{Caunus Theater}

The theater is not the only one of the buildings of Caunus that has survived in a good state of preservation, but it is also one of the best-preserved Ancient Hellenic Theater among the ones in Anatolia. ${ }^{6}$ Specifically due to its topographical location, the theater presents a magnificent view and has become a centre of attention for the past visitors to the city. ${ }^{7}$ It is one of the important specimens for the Asia Minor theater typology ${ }^{8}$ and is the only entertainment building of the city. This makes one think if it also served as an odeon and bouleuterion. ${ }^{9}$

It is well-known that theaters, in general, are one of the main important elements of the Ancient cities and the location of the theater affects, and is affected by the morphology of the cities. ${ }^{10}$ The Caunus Theater is also an architectural structure that must be read through the natural context and the relationship established with the city.

\footnotetext{
4 Martienssen, 1963, 3.

5 Martin, 2004, 184.

6 Öğün vd., 2001, 53; Serdaroğlu, 1968, 133.

7 Hoskyn, who had visited Caunus in 1840, writes for Caunus Theater that even though the craftsmanship is inferior, the building is in relatively good shape. Hoskyn, 1842 143; Collignon, 1877, 342; Bean,

1953, 14

8 Serdaroğlu, 1968, 133; Aristodimou, 2005, 3; Ferrero, 1988, 35.

9 Öğün, 2001, 55; Abbot, 1907, 49-56 writes in detail that in the Roman Period, theaters had played the role of today's media, and were spaces where public opinion on political issues were heard.

${ }^{10}$ Ferrero, 1988, 19.
} 


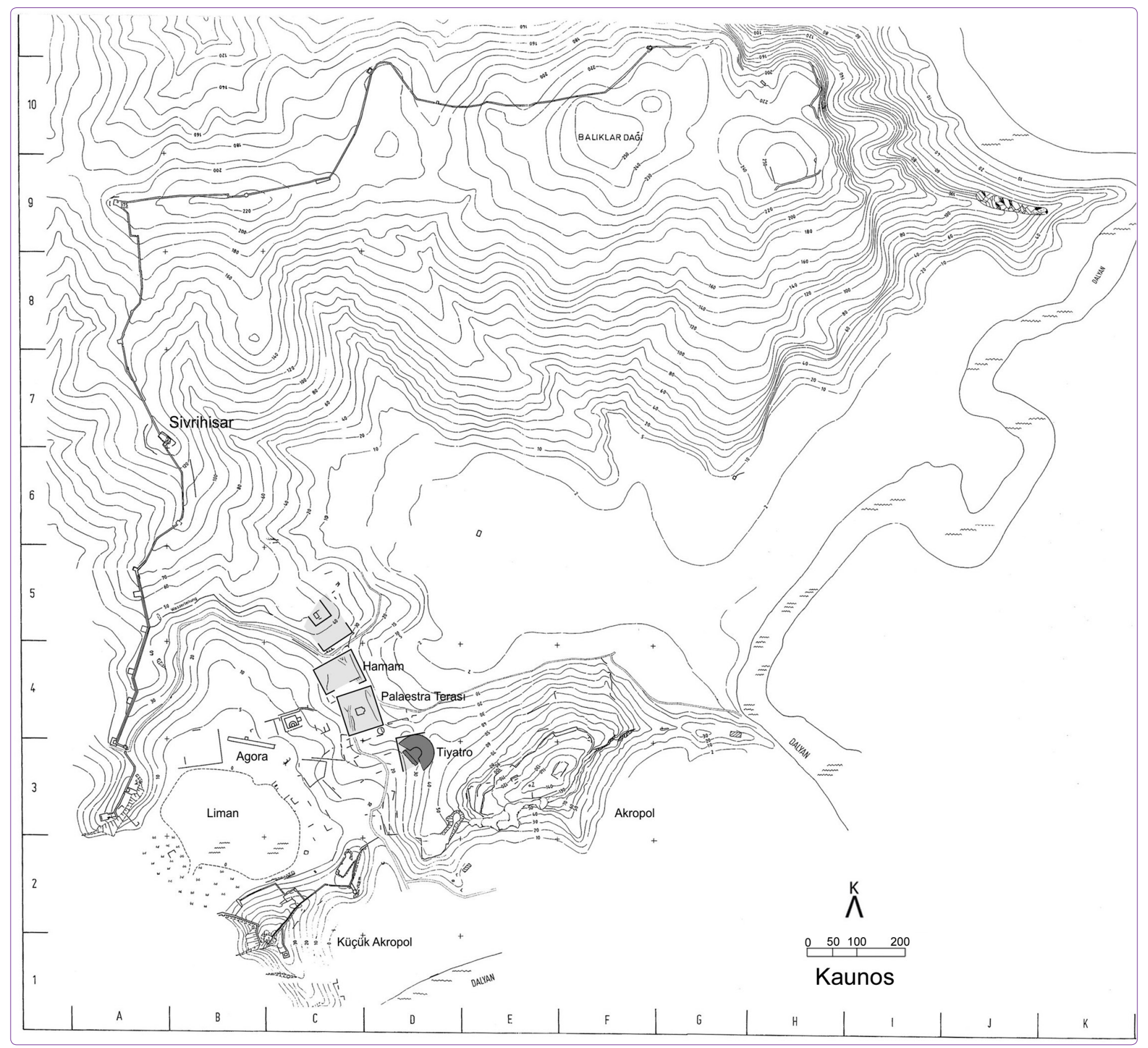

Figure 1. Site plan of Caunus City ( Archive of Caunus Archeological Excavation).

\section{Work Done At the Caunus Theater}

In the first few years of the excavations, and specifically in the 1980's, while cleaning of the earth layers in the stage building (Scene), ${ }^{11}$ several trials for the restoration of the eastern side of the surrounding wall (cavea wall) were performed. Fairly comprehensive reports and drawings were published by Ümit Serdaroğlu, ${ }^{12}$ who was a member of the team at the time, and later by Bernardi Ferrero. ${ }^{13}$ The first detailed survey ( $1 / 50$ ratio) of the scene was performed in

\footnotetext{
${ }^{11}$ Öğün, 1968; Öğün, 1972; Öğün, ${ }^{12}$ Serdaroğlu, 1968, 133.

1973; Öğün, 1974; Öğün, 1983; ${ }^{13}$ Ferrero, 1969, 210; Ferrero, 1988, 298.
}

1986, using ruler and plumb line. ${ }^{14}$ The first survey of the seating area (theatron) was drawn in $1995^{15}$ (Fig. 3), using the same methods and the first photogrametric measurement of the cavea wall was done by S. Akerdem. Extensive excavation work at the left of the vault entrance from the North that had began in 2005, has uncovered a monumental "Theater Fountain", which, as far as known, is the largest among the theater fountains discovered by now. ${ }^{16}$

\footnotetext{
${ }^{14}$ The drawings in the Caunus Excava- tion Archive are prepared by A.Z. tion Archive are prepared by N.O. Dalyancl.

Ozer.

${ }^{16} \mid$ şık, 2009b, 38
} 


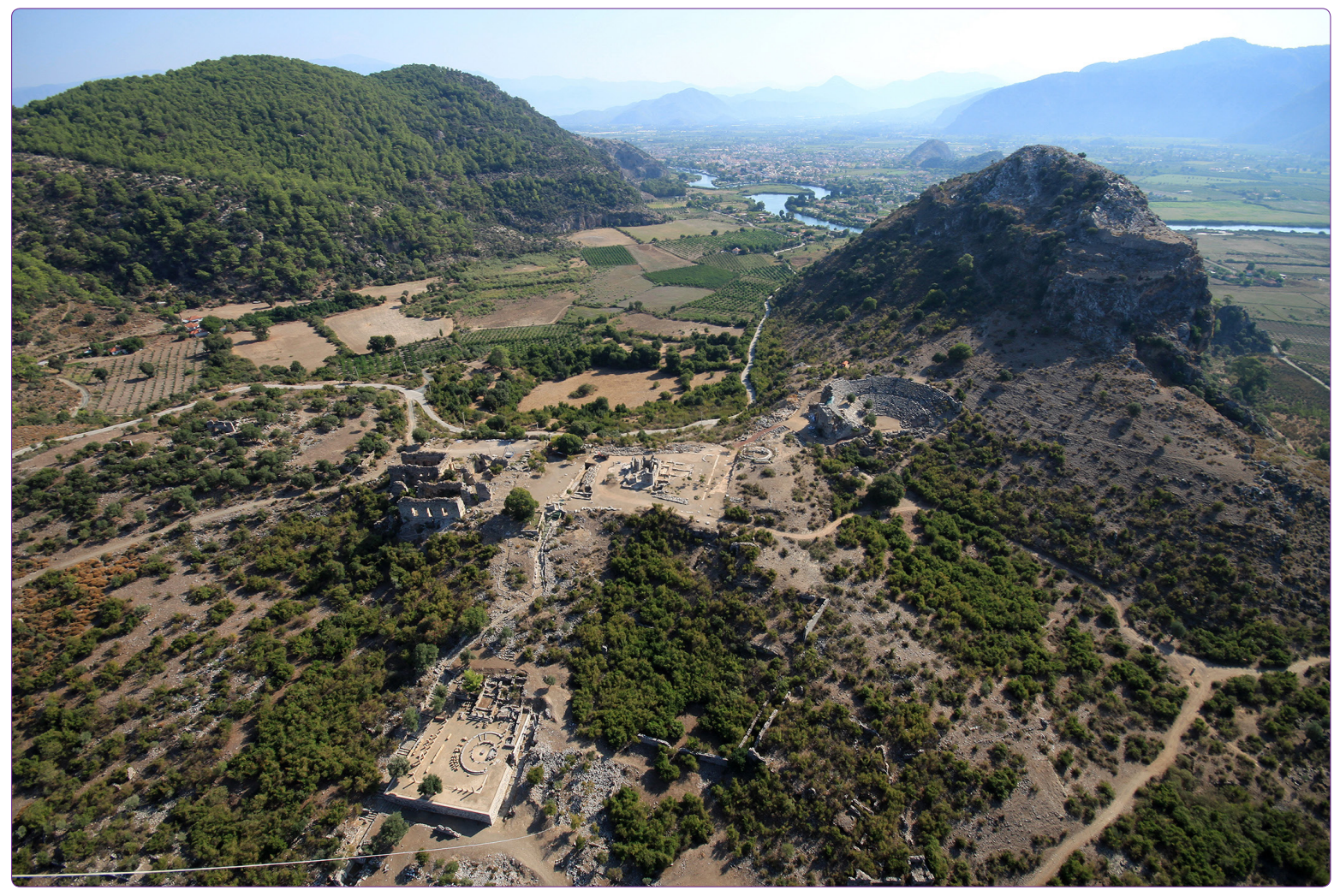

Figure 2. Aerial photograpy of Caunus Theater on the slope of the Grand Acropole (C. Işık).

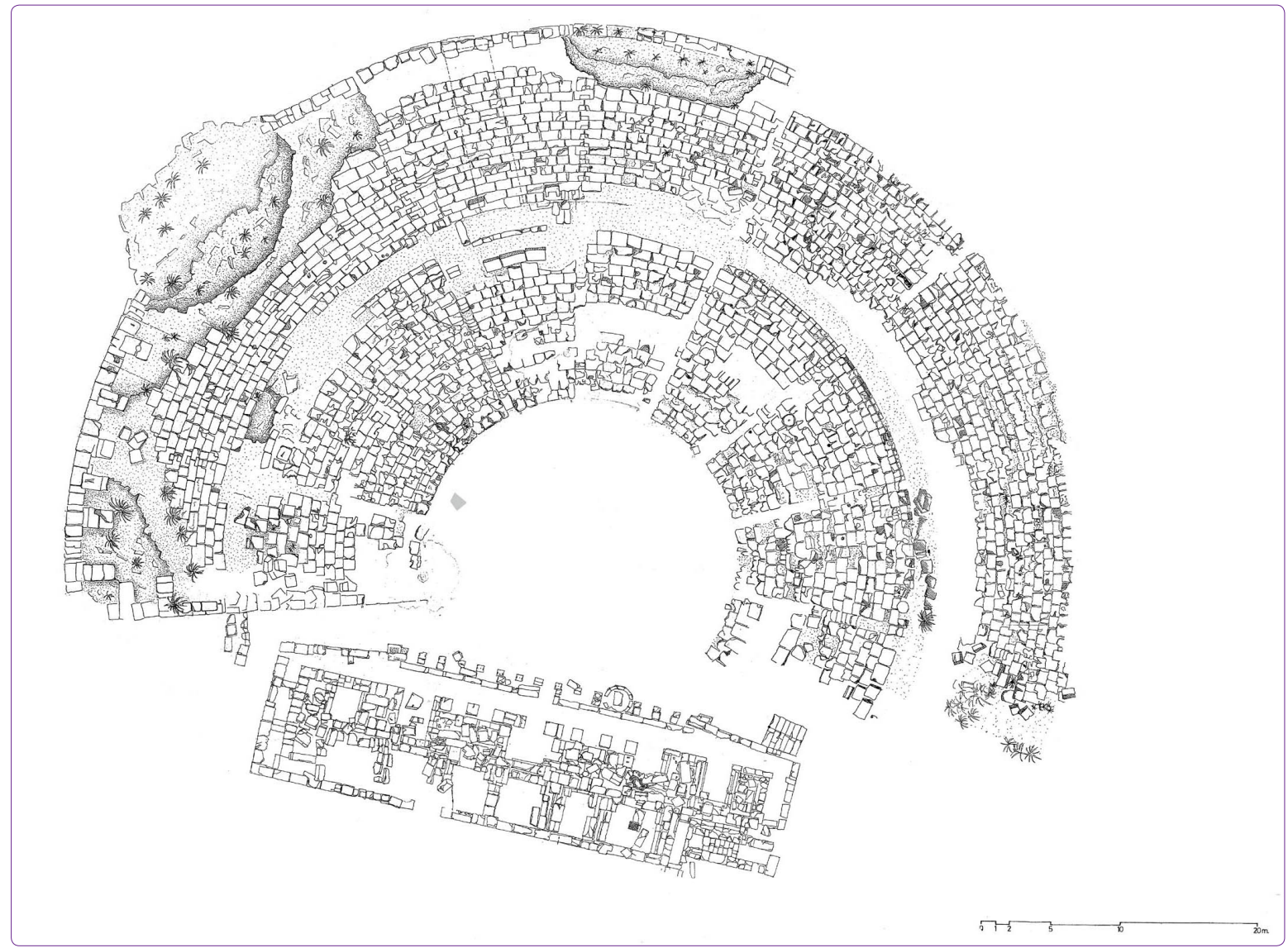

Figure 3. Plan of the theater which was drawn in 1995 (Archive of Caunus Archeological Excavation). 


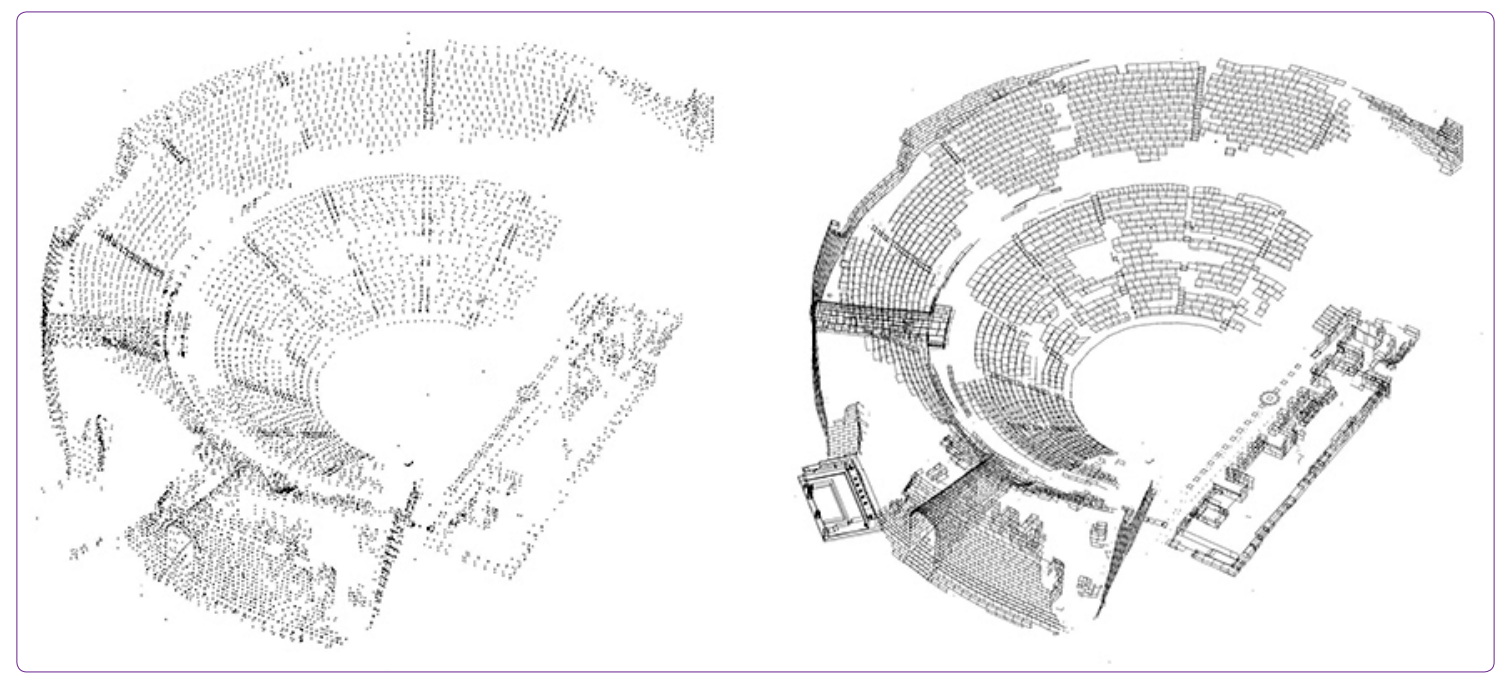

Figure 4. Measuring points and drawings in digital format (by Authors).
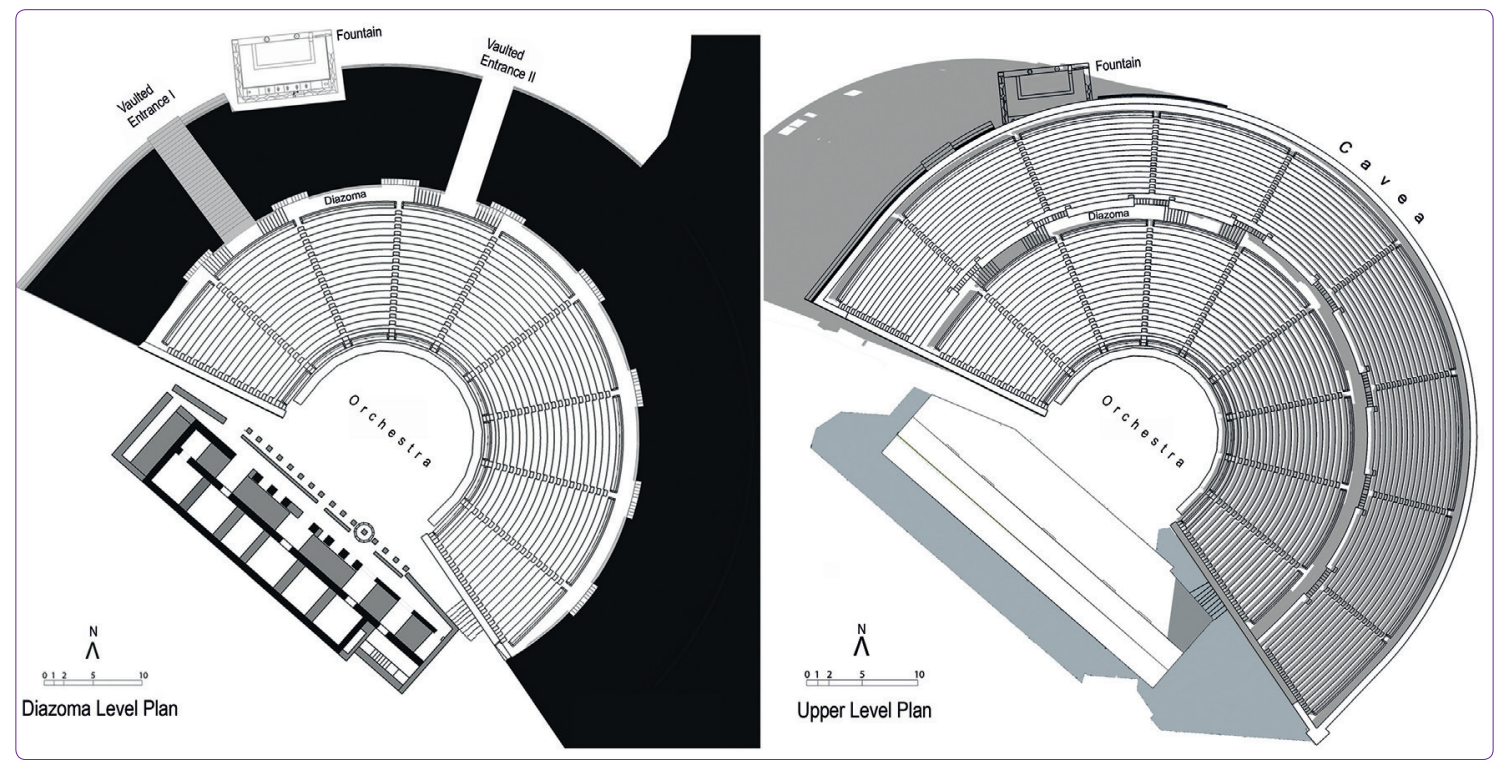

Figure 5. Plans of the theater (by Authors).

As can be seen, all the documentations about the theater done by now were prepared in two dimensions, in line with the restrictions of the times. But, it has now become possible to document first the buildings one by one, and then the whole city in 3D using the currently available measuring equipment. In the research conducted, all structural elements such as the seating steps of the theater, cavea wall, vaulted entrances, stage building have been measured in detail and coordinates have been obtained. These helped to record the fundamental geometry of the theater, its dimensions and its current situation and using the coordinates, the theater has been simulated in 3D in digital format. A detailed survey of the current situation of the theater in digital format 3D picture of it is now obtained (Fig. 4). This will be a solid reference for any future academic research on Caunus Theater.

\section{The Formal Analysis of the Caunus Theatre}

Caunus Theatre encompasses a cavea with a diameter of 76 meters, and a stage area with a length of 38.5 meters and width of 11.20 meters. The total area is 3,280 $\mathrm{m}^{2}$. The stage building is separated from the cavea with side entrances (parodos). Cavea is built in typical Hellenistic theatre characteristic with its shape larger than half a circle. ${ }^{17}$ The seating capacity is calculated to be approximately 4,500 for person..$^{18}$ Limestone is used in the seats and steps, and due to this material's properties, most of these are now eroded (Fig. 5).

Vitruvius, states that the theaters must choose the right wind direction when choosing the location, ${ }^{19}$ that's one of

\footnotetext{
17 Vitruvius, 1914, 146-152. cms width per seat.

${ }^{18}$ This figure is calculated using $60{ }^{19}$ Vitruvius, 1993, 102.
} 
the main reasons that Cavea faces southwest, taking the wind and the ligth into account. The spectators can have a view of both the city and the sea, which presents a natural scene in the background. The way the cavea is situated is of utmost importance, for it is essential that the actors and the spectators are not disturbed by the sun or the wind. ${ }^{20}$ The upper seats have a majestic view of the city and the sea. In the Hellenistic theaters, where there is either no stage building or a low level building, natural scenery that is in the domain of the spectators present a background to the play, or even act as a natural scene for the play. ${ }^{21}$

At Caunus Theater, which uses the environmental properties as design criteria, the northeast of the cavea is situated on the main rock, and other parts are placed on the support wall called analemma. This wall, with its majestic appearance, is the most impressive structural element of the theater. The wall, supporting the cavea, is a quite low level in the northeast, but it reaches 15.50 meters at the west end, and 5.80 meters at the South.

After the discovery of the monumental fountain in 2005 , it was found out that analemma forms a 11.80 meter wide niche, with depths of 3.25 meters towards the east and 1.00 meter towards the west. ${ }^{22}$ The fountain with dimensions of $10.60 \mathrm{~m} \times 6.00 \mathrm{~m}$ is within the niche. The traces on the niche abutment shows that a single vault with a height of 5.50 meters is used. The back wall of the niche is a terrace wall, and was older than analemma. In terms of craftsmanship and stone quality, it is in line with the terrace wall behind the stage building, which is built at an angle of 45 degrees. It is not yet known if these walls belong to the same terrace or not. Possibly, during the enlargement of the theater, ${ }^{23}$ to be able to continue using the fountain, it was left where it was, and circumvented by the new analemma, forming a niche. But the statical sensitivity due to the wide spacing (span) over the niche, resulted in the collapse of the cavea onto the fountain during an earthquake. The archaelogical excavations in this area have been going on. ${ }^{24}$

The inner part of the analemma, which is built using travertine blocks, is filled with chipped stones from the main rock. This forms a structure in itself. The wall gets thicker towards the ground and there is a skillfully made cascades. At the height of 0.48 meters from the ground, the wall moves inside by 0.40 meters, from there, at 0.51 meters height, it moves a further 0.32 meters inside, and

\footnotetext{
${ }^{20}$ Ferrero, 1988, 28. He mentions the the cavea wall is just wide enough importance of West and South in for a person to pass. Işık, 2009a, the Anatolian theaters, and writes 19. Also, a niche above the cavea that Southwest is equally impor- wall is rarely seen. That is why in all tant. He cites Alabanda, Aspendos, the previous drawings, analemma Milet, Hierapolis ve Side theaters as is drawn without a niche. examples. $\quad{ }^{23}$ Işık, 2009b, 40.

${ }^{21}$ Wycherley, 1986, $130 . \quad{ }^{24}$ Işık, 2009a, 1; Işık, 2009b, 33; Işık,

22 The gap between the fountain and 2011, 17; Özer, 2015, 52-54.
}

with similar patterns, it moves inside by 0.07 meters at four times. The wall thickness at the upper level is 1.10 meters, and at the lowest level, it is 2.10 meters. The western corner of the cavea wall has collapsed and this gives us a chance to see the inner part of the wall and understand its static order. Here, we can also observe ledges with dimensions of $1.00 \times 1.60$ meters inside the wall poiniting towards the filling under the seat rows. These ledges have no rhythmic order between them. The distances between these ledges, from the edge of the wall to the vault are $3.30,2.70,2.30,3.30$ and 3.90 meters. One of the ledges is situated on the entrance vault, and the reason for this is hard to explain (Fig. 6).

\section{Entrances}

There are four entrances to the theater. Two of those are above the cavea wall, and they open to the diazoma through vaulted corridors. The other two are parodoses connected to the orchestra. The necessity to enter the theater from multiple levels due to the topography, has been solved through the use of the two entries above the cavea wall. On the upper level, the vaulted entrance (Vaulted Entrance II) at the northeast is 3.30 meters wide and 2.15 meters high. The surface with an elevation of $2 \%$ towards outside is covered with large stones. It can be observed that this entrance was once closed. The passage from here to the diazoma is made possible with 1.70 meter wide stairs comprising of 8 steps.

The other vaulted gate (Vaulted Entrance I) which is at the lower level has steps. A platform is at the end of 30 steps, each with a height of $21 \mathrm{cms}$, and from there, there is a passage through left and right to the diazoma using 9 steps. This vaulted entrance is 3.75 meters wide, its height is 7.85 meters at the lower level, and 2.00 meters at the upper level.

At the third entrance which is at the northwest, there are no stairs when passing from parodos to the orchestra. Right here, where cavea wall and the stage building come closest to eachother, it can be understood from the uncovered doorstep that at one point, the parodos was closed by a door with dimensions of $2.60 \times 0.60 \mathrm{~m}$.

Fourth entrance is at the parodos in southeast and is reached through steps. Average height of the steps is 20 $\mathrm{cms}$, and the widths vary between $38-44 \mathrm{cms}$. Only the first 8 steps are visible. The above steps are under debris and we are not sure how many of them there were, and where they led to.

\section{Cavea (Seats)}

Cavea has been separated into 9 radial slices of seating rows (kerkides) with 10 klimakes, each 0.60 meters wide. Diazoma, is 1.70 meter wide with a 1.50 meters high side wall, which horizontally separates the upper and lower 


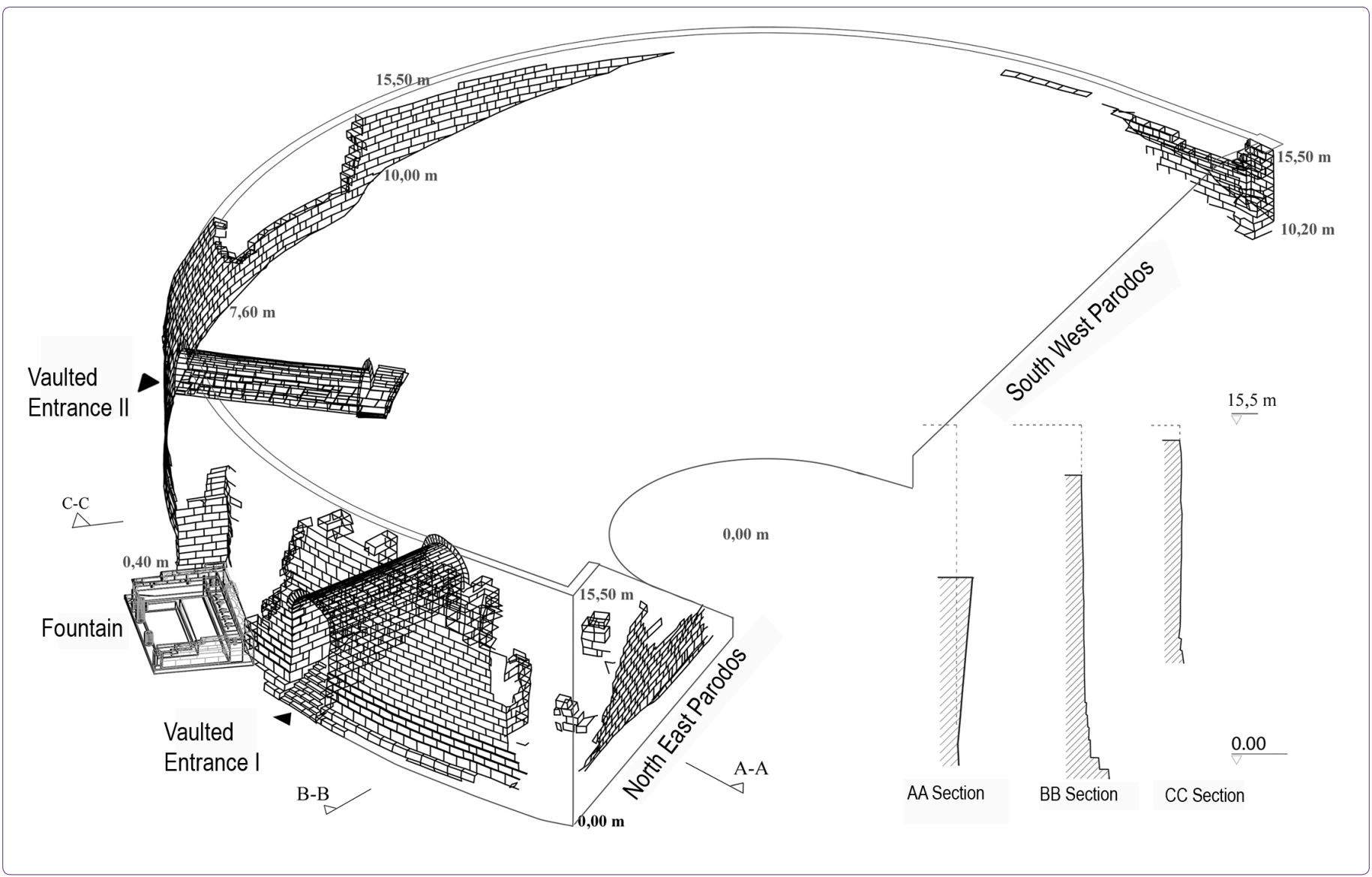

Figure 6. Analemma wall and the sections (by Authors).

level seats. ${ }^{25}$ There are 18 rows of seats in the lower level, and 16 rows in the upper level. From the diazoma to the first row at the upper level, there are 7 steps that are 70 $\mathrm{cms}$ wide. Each step is $21 \mathrm{cms}$ high and $33 \mathrm{cms}$ deep. In the lower cavea, the seating rows are $78 \mathrm{cms}$ deep and $41 \mathrm{cms}$ high, whereas in the upper level rows, the depth is $70 \mathrm{cms}$ and the height is $40 \mathrm{cms}$. The vision curves of the rows are also different: in the lower levels, the view angle is 31 degrees, but at the upper levels, this figure is 34 degrees. The reason behind these differences are the pursuit to present the spectators the best possible view (Fig. 7, Fig. 8).

In many places of the seat rows, there are two types of dents. A group of those, with diameters of $26-27 \mathrm{cms}$, and depth of 21-22 cms were surely drilled to bury the wooden bars that hold the covers against the sun and the rain. Some others with diameters of 21-22 cms, which are at the lower middle part of the seating units, were possibly drilled to tie

\footnotetext{
${ }^{25}$ Vitruvius, On page 138 of his book, "The Ten Books on Architecture", he mentions that, for the sound to reach to the spectators at the upper levels, the height of the diazoma should never exceed its width. At the Caunus Theater, the dimensions of $1.70 / 1.50 \mathrm{~m}$. ensures that. On the same page, he writes that, if the line drawn from the end of the lowest row of seats to the highest row of seats, touches the ends of all rows, that would ensure that the sound will not encounter any obstacles. Caunus Theater delivers in this aspect, too.
}

the tents by ropes to prevent them from falling down.

\section{Orchestra}

In the ancient Greek theater, orchestra, had the same function as today's stage. There was always a close interaction between the acitivities on the stage ${ }^{26}$ and the spectators, so the distance between the actors and the spectators was vital. ${ }^{27}$ In the early period, the surface of the orchestra was not elevated as it went towards the seats. In later periods, as elevated platforms were used, the type of the plays also changed. ${ }^{28}$ As the play moved further away from the spectators, orchestra lost its importance and "stage" took over.

The Orchestra of the Caunus Theater has a diameter of $17.50^{29}$ meters and its surface is made of compressed earth..$^{30}$ Lowest level seats are on the same level as the orchestra. Orchestra is directly reachable through parados in the northwest, whereas there are stairs in the southeast parados.

\footnotetext{
${ }^{26}$ Theater was not only a place where ${ }^{28}$ Bieber, 1954, 279. plays were acted, but also a venue ${ }^{29}$ This figure does not include the wawhere poems were recited and his- ter accumulation channels around torical events were relayed to the the cavea. crowds.

${ }^{27}$ Bieber, 1957, 206.
} 


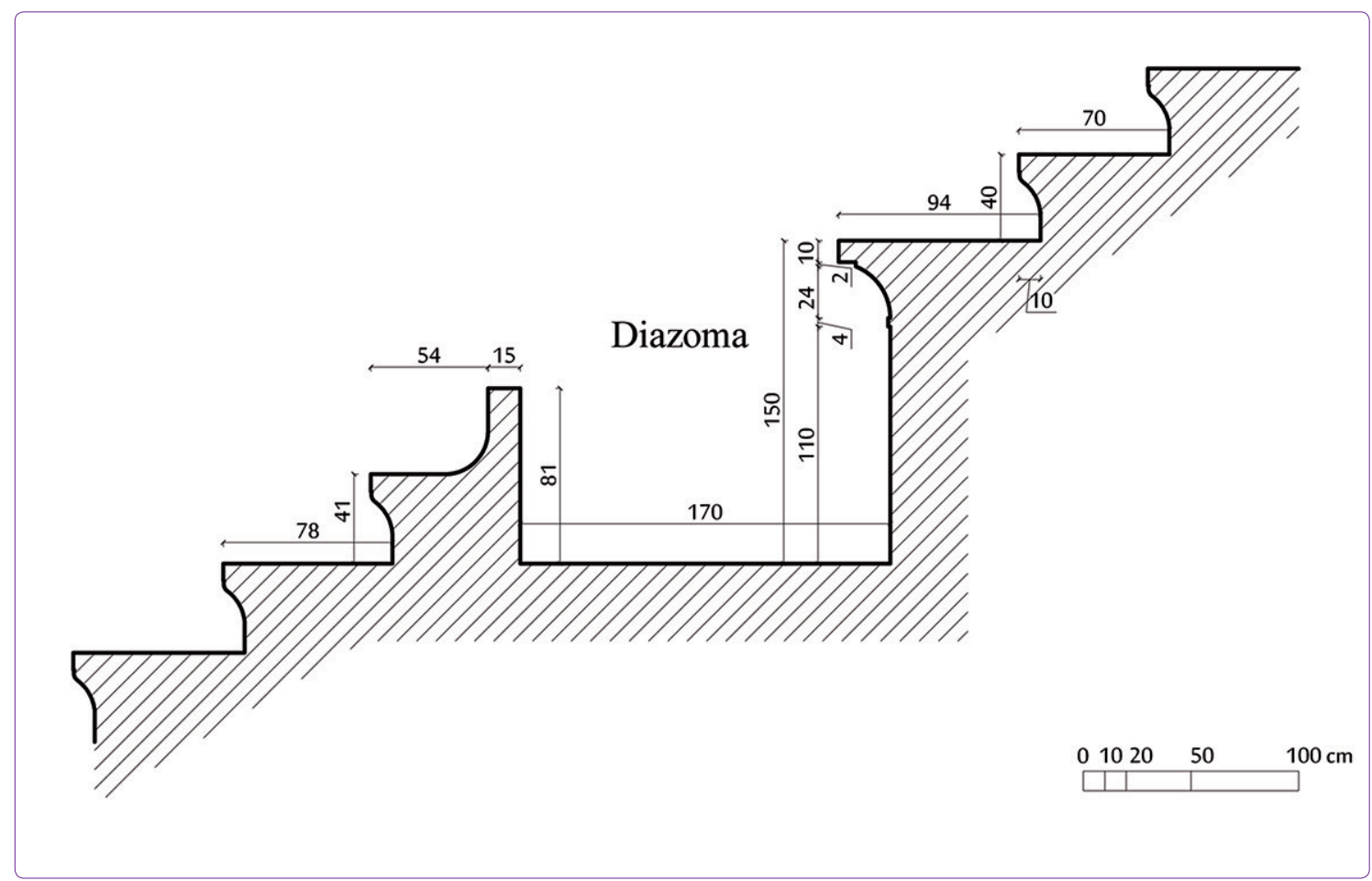

Figure 7. Section from the cavea steps (by Authors).

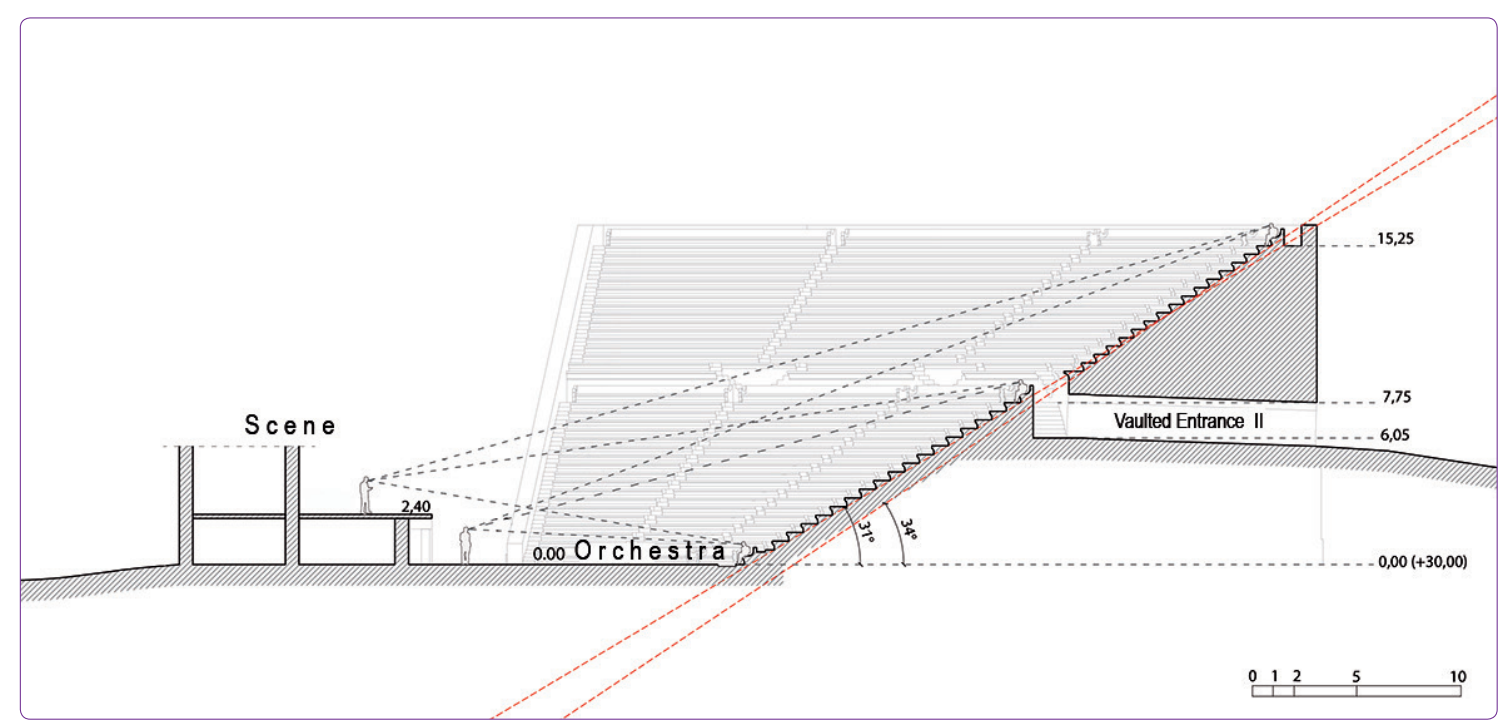

Figure 8. The vision curves of the rows (by Authors).

At the Caunus Theater, as in other theaters, ${ }^{31}$ the drainage channel is running around the edge of the orchestra. In most examples the channel is not covered. ${ }^{32}$ At points where the Orchestra is situated onto the main rock, a water channel is dug through the main rock for discharging the water. The width of this channel is 0.85 meters (Fig. 9). Most channels like Caunus' are not covered..$^{33}$ These

\footnotetext{
${ }^{31}$ Efes, Bodrum, Priene, Dodona, visited by the research team at variEpidauros, Sikyon, Philippo and ous times.

Athens Dionysos theaters are the ${ }^{32}$ Antoniou, 2015, 6.

ones referred here. They have been ${ }^{33}$ Kollyropoulos, 2015, 6.
}

uncovered channels are filled with water to cool the environment as an alternative in the hot days. ${ }^{34}$ Along the cavea, the waste water collected in the channel is discharged under the stage building. ${ }^{35}$ During the excavations in 2015, one of the exits belonging to the water discharge system was revealed in the northeast of the stage building.

\section{Stage Building}

The part of the theater which has changed the most along the years, is the stage building. Following the excava-

\footnotetext{
${ }^{34}$ Durm, 1892, $218 . \quad \quad 35$ De Feo, 2014, 3950; Kollyropoulos, 2015, 1.
} 


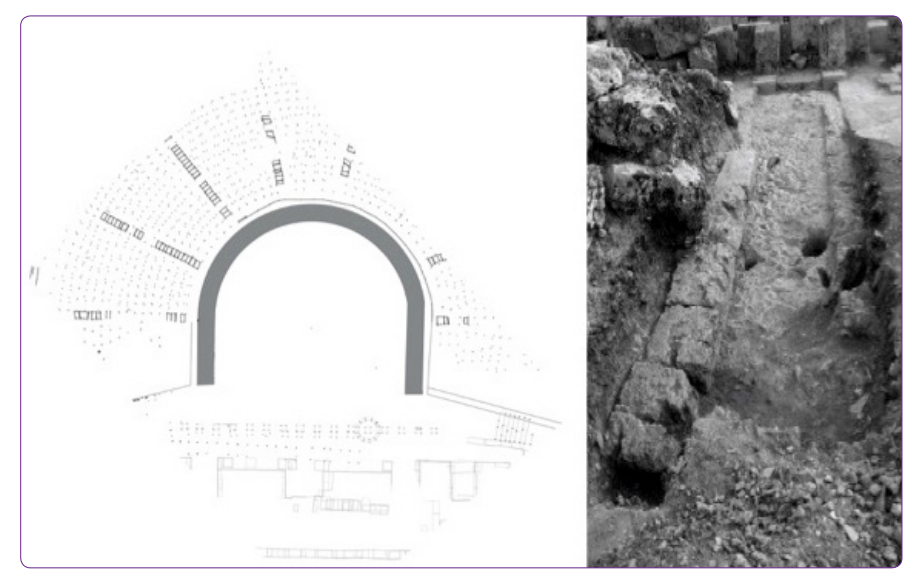

Figure 9. The waste water channel near the orchestra (by Authors and Archive of Caunus Archeological Excavation).

tions right in front of the stage building in 1982, most of the proskenion was uncovered and many architectural pieces, as well as some statue parts were discovered. ${ }^{36} \mathrm{~A}$ detailed examination of the stage building reveals the craftsmanship and material quality that belongs to different periods. The original dimensions of the building were 21.75 meters to 8.40 meters, but it was enlarged to 38.50 meters to 11.20 meters. Sandstone blocks are used in building the two-level stage. From the traces on the low $(2.40$ meter high) ceiling, we can tell that vault system is used. There are some stairs on the east side that descends to the entrance level, but it is not certain where they lead to. In its current condition, stage building has many unknowns and there is lots of room for further research into it.

\section{Conclusion}

We can summarize the main points of the formal analysis of the theater as follows:

\section{A. In Relation To the Topography:}

Its topography is one of the main determinants in the design of the theater. The direction the theater faces is the steep western slope of the Acropolis. On the other hand, to have a view of the harbour and the city, the building is rotated skillfully to southwest. The cost of this has been the need to build high cavea wall on the West of the cavea. But, this also had the advantage to connect to the diazoma through vaulted entrances that pass within the walls and this helped to solve the problem of spectator circulation.

\section{B. Relationship With the City:}

The building is possibly connected to the city centre/ harbour agora through a Street in the southwest. Topography is suitable for the connection of these two important urban structures. This view is supported by two parallel late period wall remains. As it is deduced from the drawings, these two walls constitute a street fabric (Fig. 10).

\footnotetext{
${ }^{36}$ Öğün, 1983, 240.
}

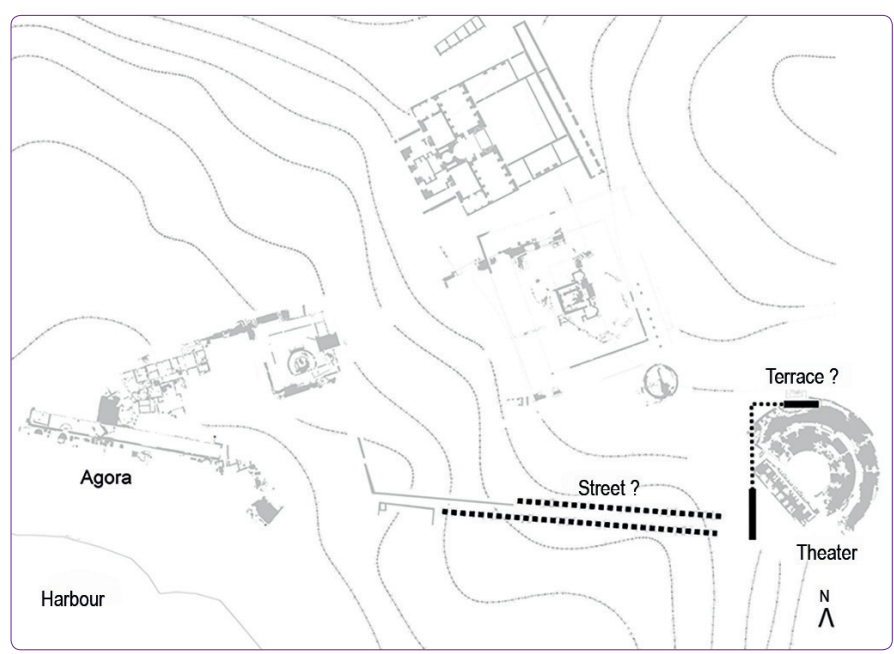

Figure 10. The relation between the street and the terrace (by Authors).

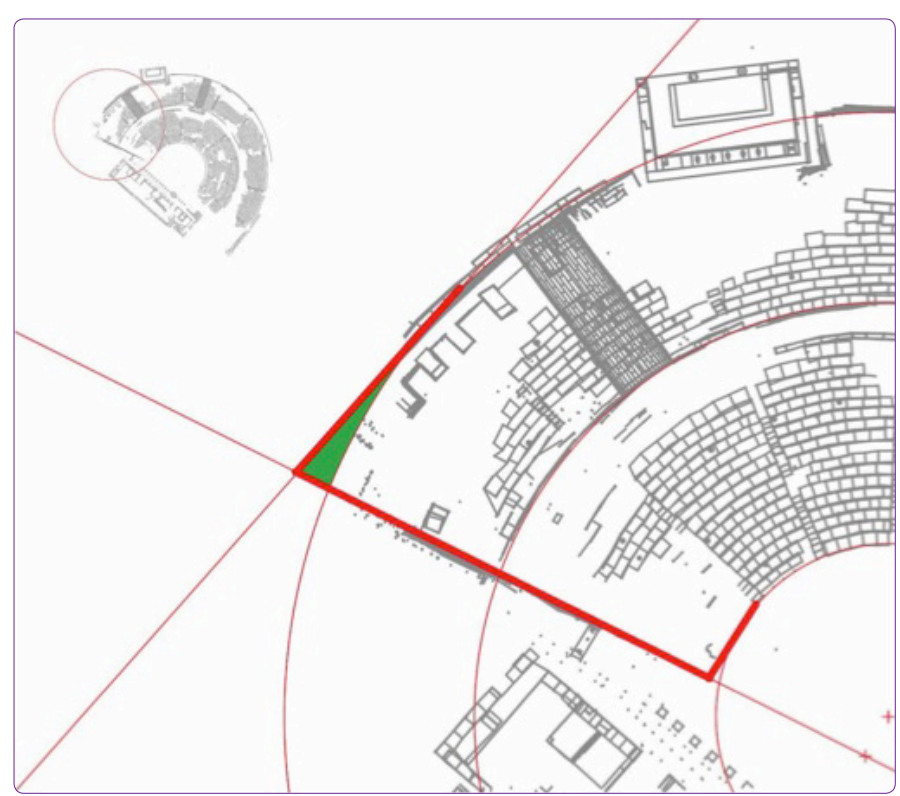

Figure 11. The relation between the Cavea and Parados walls (by Authors).

\section{General Character of the Theater:}

The shape of the cavea wall of the Caunus Theater is as drawn in earlier studies, is not a structure of a circular character, but of a horseshoe shape. Cavea wall, loses its radial characteristic at the eastern and western ends (first and ninth kerkides), opens up outwards and takes on a linear character. This conclusion is mainly achieved by precise measurement of the well- preserved cavea wall (Fig. 11).

Vitruvius' Greek theatre principles tell us that, the orchestra circle is taken as the focal point and within it, three equal sized squares are placed, each of them touching the outer circle. ${ }^{37}$ The perimeter of the circle should touch the back wall of the stage, and one side of the bottom square

\footnotetext{
${ }^{37}$ Vitruvius, 1904, 151.
} 


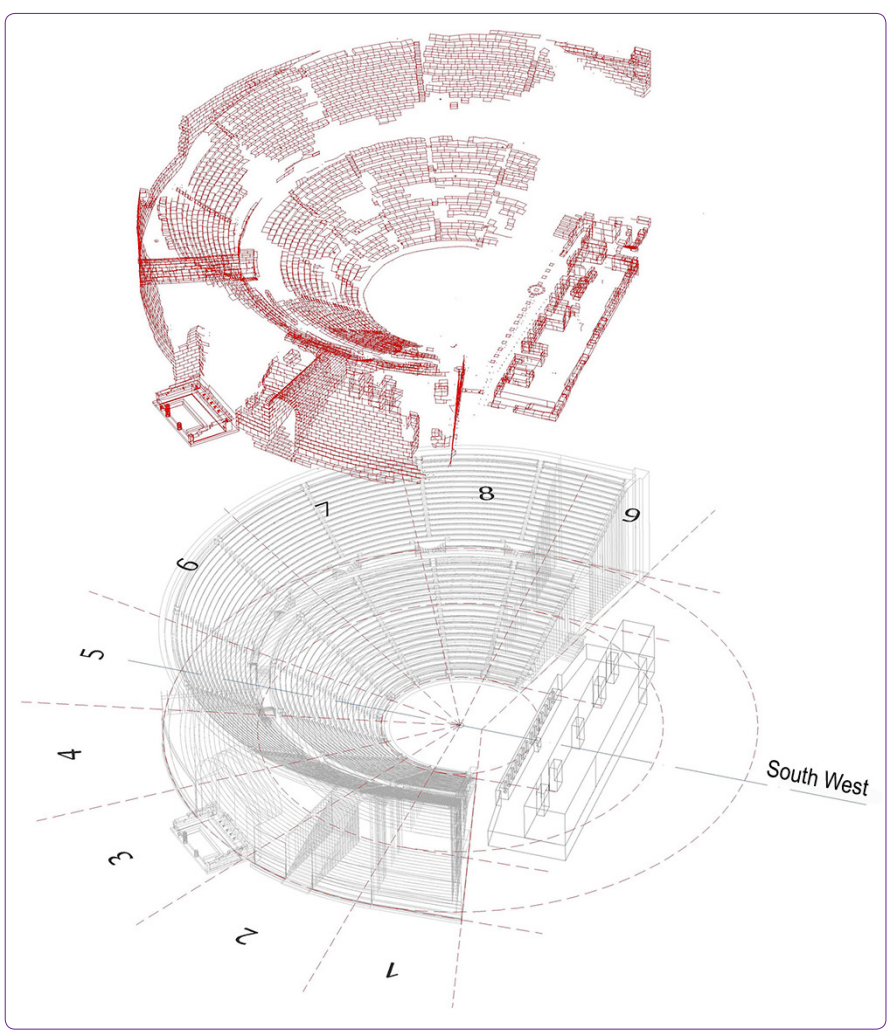

Figure 12. Current state and probable form of the theater (by Authors).

should point to the front of the stage. ${ }^{38}$ According to the design principles proposed by Vitruvius, stage building should have been closer to the cavea than it actually is. On the other hand, the direction of the parodos walls do not point towards the centre of the cavea arch, but outwards from the centre, towards a second centre. As we query Vitruvius principles specifically for the Caunus Theater, even though, with its circular orchestra, horseshoe shaped cavea, and its seating rows at the stage axis, it does conform to the standards of the Greek theater, the location and the height of the stage $\mathrm{e}^{39}$ are not in line with those standards. Caunus Theater, as explained in earlier research and publications, is a Roman period theater with Greek origins ${ }^{40}$ (Fig. 12).

There is no doubt that, this 3D digital record of Caunus Theater obtained by this work is an important document of the present day. It is important because; it will form the basis of all works such as functional, structural, typological, ergonomic, lighting, acoustics, restoration and restitution which will be studied afterwards on Caunus Theater.

\footnotetext{
${ }^{38}$ For example, Priene, Efes and Delos theaters are among those Greek type theaters that conform with Vitruvius principles. Sear, 1990, 249.

${ }^{39}$ The height of the stage has been one of the more important issues for discussion among researchers. Vitruvius' argument that the stage height should not be less than 10 feet, and more than 12 feet has been criticized freely. White, 1891, writes in page 202 that, the plays of comic playwright, Aristophanes(BC 456 - BC 386) could not have been played in the theaters described by Vitruvius. Haigh, 1890, 277-282 and Goodel, 1897, 1-18 They explain that Vitruvius' principles cannot hold true for the width and height of the stage.

40 Serdaroğlu, 1968, 133; Öğün, 2001, 53.
}

\section{References}

Abbott, F.F. (1907) "Theatres in Asia Minor" American Philological Association, Sayı 38, s. 49-56.

Aristodimou G. (2005) "The Theater as a Factor in Roman Politics under the Republic" Encyclopaedia of the Hellenic World, Asia Minor.

Bean, G.E. (1953) "Notes and Inscriptions from Caunus", The Journal of Hellenic Studies, Sayı 73, s. 10-35.

Bieber, M. (1954) "The Entrances and Exits of Actors and Chorus in Greek Plays" The American Journal of Archeology, Sayı $58 / 4$, s. 277-284.

Bieber, M. (1957) "Greek Theatre Production by T. B. L. Webster" The American Journal of Philology, Sayı 2, s. 206-213.

Collignon, M. (1877) "Emplacement et ruines de la ville de Kaunos", Bulletin de Correspondance Hellénique, Sayı 1, s. 338346.

De Feo, G.- Antoniou, G. - Fardin, H.F. - El Gohary, F. - Yun Zheng, X. - Reklaityte, I. - Butler, D. - Yannopoulos, S. - Angelakis, A.N. (2014) "The Historical Development of Sewers Worldwide". sustainability open access, s. 3936-3974.

Durm, J. - Ende, H. - Schmitt, E. - Wagner, H. (1892) Handbuch Der Architektur, Darmstadt, Verlag von Arnold Bergstrasser.

Ferrero, D. B. (1969) Teatri Classici In Asia Minore 2, Roma, L'erma Di Bretschneider.

Ferrero, D. B. (1988) Batı Anadolu'nun Eski Çağ Tiyatroları, Ankara, Italyan Kültür Heyeti Arkeoloji Araştırmaları Bölümü.

Goodell, T.D. (1897) "Dorpfeld and the Greek Theatre" The American Journal of Philology, Sayı 18, s. 1-18.

Haigh, A.E. (1890) "Dr. Dörpfeld's Theory about the Logeion in Greek Theatres" The Classical Review, Sayı 4, s. 277-282.

Hoskyn, R.E. (1842) "Narrative of a Survey of Part of the South Coast of Asia Minor; And of a Tour into the Interior of Lycia in 1840-1; Accompunied by a Map" The Journal of the Royal Geographical Society of London, Sayı 12, s. 143-161.

Işık, C. (2009) "Kaunos Tiyatrosu Çeşmesi" Bütün Dünya Dergisi, Sayı 11, s. 38-44.

Işık, C. (2009) Kaunos - Kbid 07 Kazı - Konservasyon - Restorasyon - Onarım -Arkeolojik Park Çalışmaları ve Etkinlik, 30. Kazı Sonuçları Toplantısı, T.C. Kültür ve Turizm Bakanlığı Yayın No : 3171-1 Kültür Varlıkları ve Müzeler Genel Müdürlüğü Yayın No: $130-1$, s. 1-10.

Işık, C. (2011) "Kaunos 2009 Çalıştay - Kazı - Araştırma Restorasyon -Konservasyon - Onarım ve "Arkeolojik Park" Çalışmaları", 32. Kazı Sonuçları Toplantısı, T.C. Kültür ve Turizm Bakanlığı Yayın No: 3267-4 Kültür Varlıkları ve Müzeler Genel Müdürlüğü Yayın No: 147-4, s. 17-32.

Kollyropoulos, K. - Antoniou, G. - Kalavrouziotis, I. - Krasilnikoff, J. - Koutsoyiannis, D. - Angelakis, A. (2015) "Hydraulic Characteristics of the Drainage Systems of Ancient Hellenic Theatres: Case Study of the Theatre of Dionysus and Its Implications." ASCE, s. 1-32.

Martienssen, R.D. (1956) The Idea of Space in Greek Architecture, Johannesburg Witwatersrand University Press.

Martin, R. (2003) Greek Architecture, Paris, Electa Architecture.

Öğün, B. (1967) “Kaunos Sondajları (1966-1967)”, Türk Arkeoloji Dergisi, Sayı XVI, s. 121-132.

Öğün, B. (1972) Kaunos Kazıları 1968-1970, Türk Arkeoloji Dergisi, Sayı XIX-II, s. 195- 202. 
Öğün, B. (1973) Kaunos-1971, Türk Arkeoloji Dergisi, Sayı, XX-I, s. $163-167$.

Öğün, B. (1974) Kaunos Kazıları 1972, Türk Arkeoloji Dergisi, Sayı, XXI-I, s. 133-136.

Öğün, B. (1983) Kaunos Kazıları (1982) Kazı Sonuçları Toplantısı 5, Kültür ve Turizm Bakanlığı Eski Eserler ve Müzeler Genel Müdürlüğü, s. 239-240.

Öğün, B. - Işık, C.- Özer, N.O. - Diler, A. - Schmaltz, B. - Marek, Chr. - Doyran, M. (2001) Kaunos / Kbid: 35 Yılın Araştırma Sonuçları (1966-2001), Antalya, Orkun Matbaası.

Özer, N.O. - Say Özer, Y. (2015) Bir Mimarlık Laboratuvarı: Kaunos
1982-2015, İstanbul, Arkeoloji ve Sanat Yayınları.

Sear, F.B. (1990) "Vitruvius and Roman Theater Design" American Journal of Archaeology, Sayı 94, s. 249-258.

Serdaroğlu, Ü. (1968) "Kaunos Tiyatrosu Üzerine Bir Çalışma", Türk Arkeoloji Dergisi, Sayı 16, s. 133-136.

Vitruvius, (1914) The Ten Books on Architecture, London, Oxford University Press.

White, J.W. (1891) "The 'Stage' in Aristophanes" Harvard Studies in Classical Philology, Sayı 2, s. 159-205.

Wycherley, R.E. (1986) Antik Çağda Kentler Nasıl Kuruldu?, İstanbul, Arkeoloji ve Sanat Yayınları. 